\author{
Lukasz BA $K^{1}$ \\ Igor G. LOGINOV \\ Janusz MICHALCEWICZ ${ }^{3}$ \\ Victor I. SLEPYAN ${ }^{4}$ \\ Feliks STACHOWICZ ${ }^{5}$
}

\title{
CONSTRUCTION OF SCREENER ORIENTED ON APPLICATION OF PARAMETRIC RESONANCE
}

\begin{abstract}
The problem with obtaining high efficiency screening process in the coal, metal mining, building and other industries lead to invent new constructions of the screeners. The rapid progress of screening techniques and screen design was observed in the past and nowadays the development of screen is stabilized and most of equipment produced by various machines companies is very similar. In spite of this, there is always a need to improve the performance of screens. Increase capacity and efficiency of screening process on the one hand, and decrease its ecological footprint are the main goals of development of a new screening equipment. The screening machines inventive method is parametric resonance excitation of the screen sieve mesh. The model of laboratory screener based on parametric resonance for fine granular materials is presented in this paper. The working principle of the screener is included showing, that the parametric resonance screener could obtain a complex motion of the sieve, which is desirable with processing naturally wet fine granular materials.
\end{abstract}

Keywords: screener, parametric resonance, sieve, construction

\section{Introduction}

Screening is the basic process in separating mineralogical components. All of screeners are based on method of screening, which is schematically shown in Fig. 1. The material is being fed onto the sieve and next is transported along the sieve during which the feed is segregated into the oversize and undersize material. Oversize fraction consists of the whole class $C_{O}$ in the feed and part of class $C_{U}$. The rest of class $C_{U}$ are included into undersize fraction [1,2].

\footnotetext{
${ }^{1}$ Autor do korespondencji/corresponding author: Łukasz Bąk, Rzeszow University of Technology, 8 Powstańców Warszawy Ave, 35-959 Rzeszow, tel.: (17) 8651513, e-mail: lbak@ prz.edu.pl 2 Igor G. Loginov, LPMC Co., Kiev, Ukraine, e-mail: iloginov@yandex.ru

3 Janusz Michalcewicz, EUROTECH Sp. z o.o., Mielec, e-mail: j.michalcewicz@eurotech.com.pl

${ }^{4}$ Victor I. Slepyan, LPMC Co., Kiev, Ukraine, e-mail: v.slepyan@ voliacable.com

${ }^{5}$ Feliks Stachowicz, Rzeszow University of Technology, 8 Powstańców Warszawy Ave, 35-959 Rzeszow, e-mail: stafel@prz.edu.pl
} 


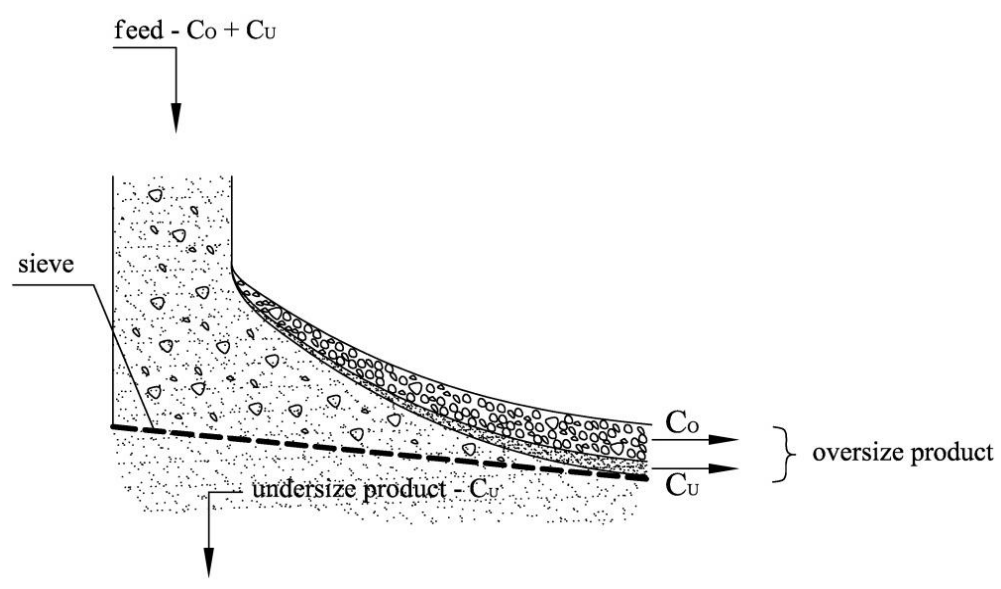

Fig. 1. Scheme of screening mechanism

In the screening process two types of resistances are distinguished: the layer resistance and the sieve resistance. Resistance of the layer has a significant impact on the screening of material thick layers. This kind of resistance is typical for the screening of a fine grade material. It is taken as difficulty of segregating layer. A difficulty of grain transition through the sieve mesh called as sieve resistance, has smaller effect. To minimalize the layer resistance impact, and increase the efficiency of the screening process the proper motion of the screen should be established. This is the challenge for engineers $[1,3]$. The rapid progress of screening techniques and screen design was observed in $19^{\text {th }}$ and $20^{\text {th }}$ century. Nowadays the development of screen is stabilized and most of equipment produced by various machines companies is very similar [4]. In spite of this, there is always a need to improve the performance of screens. Increase capacity and efficiency of screening process on the one hand, and decrease its ecological footprint are the main goals of development a new screening equipment.

Vibro-impact mechanisms, such as screeners and drilling/cutting devices, are usually designed to operate in a resonance regime RR. Then the most powerful energy flux can be achieved from the exciter to the vibrating component, and high oscillation amplitude of the target structure can be obtained using excitation of a relatively low intensity. Parametric resonance PR is the state of oscillating instability which can arise under periodic disturbance of a parameter of the structure, for example, under periodic variation of the pendulum length or the tensile force in a beam, plate or a flexible screen. Under such action, the system begins to oscillate with the amplitude growing exponentially, much faster than in the case of RR, where it grows linearly. The amplitude almost instantly reaches the maximal level defined by the system nonlinearity. The benefits are very large amplitudes of high-frequency oscillations with a high rate of the energy transfer; a wide resonant-frequency re- 
gion; low sensitivity to damping; coupled in-plane and lateral oscillations and vibro-insulation. In engineering, PR as well as flatter was studied with the goal to avoid it, since such phenomena usually lead to structural damage. However the PR since its use in properly designed vibro-impact systems seems to be very promising. These objectives can be obtained by implementation of parametric resonance in screening process.

\section{Screener construction}

Many factors are taken into account during the design of the vibrating screener's construction. The most important is to obtain the highest possibility of passing material through the cut-outs. This factor requires to design the screener in such a way as to get the most effective sieve motion in conjunction with the proper shape and spacing of the sieve cut-outs. But to obtain the high capacity screening in industry, there is also need to carry out the process continuously. This means that the material which is fed onto the sieve surface should continuously flow as a regular steam through the screening machine. Screener design aim is to obtain the highest material flow with maximum segregation efficiency simultaneously [5].

Wide range of application of vibrating screeners in different industries caused high development of their construction. Most of them are very similar and consist of the same main elements (Fig. 2). The sieve is one of the most important parts of the screen. The size of sieve cuts and its geometrical forms largely determinates the efficiency of screening process. Life of cuts geometrical form and sieve surface depend on the applied material [6]. The most popular constructions are screen deck of steel plates, screen cloth, screen deck of rubber or polyurethane fibre plates and cantilever beam/rod screen deck [7]. Industrial screening machines sometimes are equipment a multi deck construction. A superimposed sieve is mounted within a common riddle. This solution increases the capacity of screening process. The construction element which is used to fix the sieve is called riddle. The sieve stiffness and mechanical strength are determined by a riddle. Other task of this part is to transfer loads and motions onto the sieve and to move a portion of material through sieve surface. The angle of inclination and riddle movements depends on the screener suspension. This element enables a sieve movement in the specified direction and precludes unexpected motion simultaneously, which can disturb the process execution. The newest constructions contain a spring suspension [7].

Sieve periodical motion and its trajectory also depend on the type and the configuration of driving elements. Generally, eccentric vibrators and eccentric crankshafts are used to drive the screen. Eccentric vibrators are mainly applicable to the screens, which works above resonant frequency. Driven force is generated by inertia of eccentric mass. Second driving mechanism excites vibrations of screen by rotation of an eccentric crankshaft. The amplitude of vibration is 
constant and equals the size of the crankshaft shoulder $[4,8]$. Some constructions of screeners use an electromagnetic vibrator as a driving mechanism. It is mainly applied to directly excite sieve motion. Single elements are joined together by the frame. It enables a proper mate between parts. Frame connected with the support carries dynamic reaction forces of screener mass. Depending on the type of connection these forces can be damped [6,7]. Differences between screens mainly refer to the screen sieve motion. Sieve motion determinates the process execution, because of this depends the motion of grains on the mesh surface and the motion of grains in the screened layer. The single-plane screeners are the most popular screening machines. In this case the riddle vibrates in the single plane $\pi$ (Fig. 3), perpendicular to the sieve. The vibrating trajectory is flat and may take a different form: linear, circular, elliptical, complex (double frequency). A group of screening machines are based on the other kinds of sieve motion, for example circling motion (circling screens) or non-linear (spatial) motion [1].

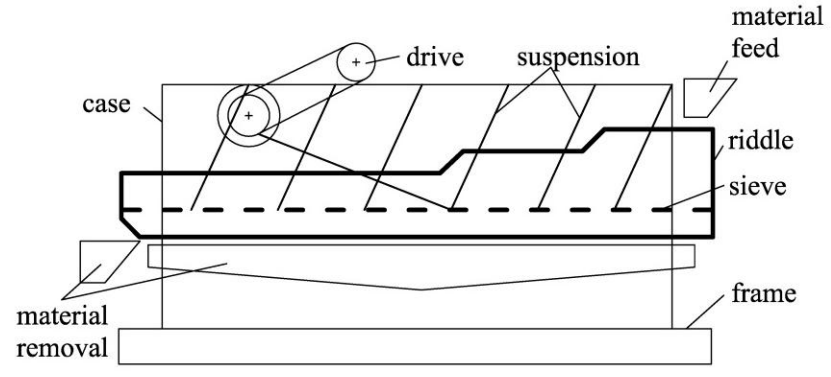

Fig. 2. Main elements of screener

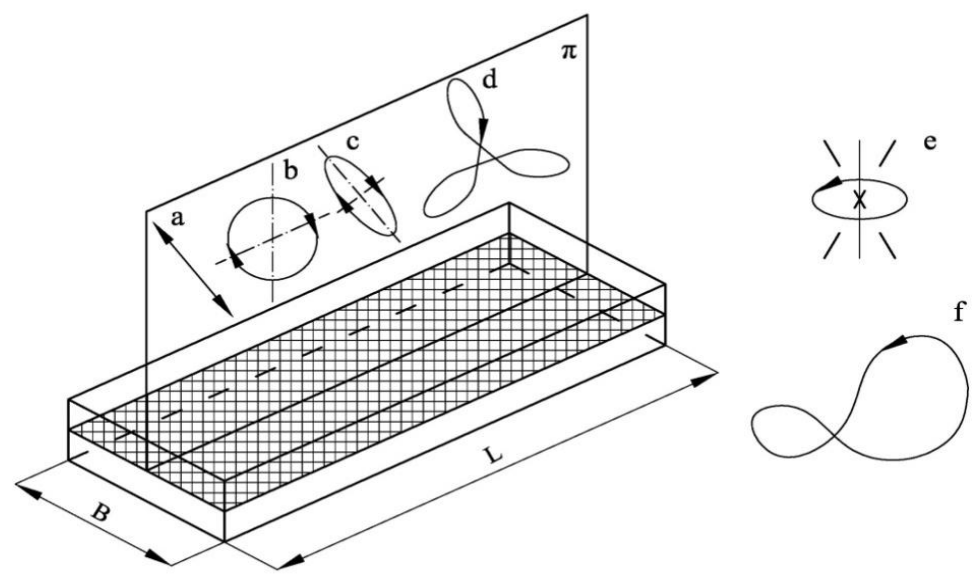

Fig. 3. Trajectories of the sieve: a) linear, b) circular, c) elliptical, d) complex (double frequency), e) circling motion (circling screens), f) nonlinear (spatial) motion 
The first PR-based vibrating screen was designed and built in LPMC. The working principle of the parametric resonance screener is based on high amplitude lateral oscillation of the sieve surface (Fig. 4). The riddle is suspended on springs, and whole assembly is mounted on the frame. Riddle construction is different from the machines built so far. It consists of two parts, which are joined together by sieve only [9]. This solution enables a complex motion of the riddle (Fig. 3) and the sieve surface. The sieve is a single plate with cut-outs. A structural material for the sieve must be used, because complex state of stresses is occurred. It is very important to apply the sieve pretension in order to stabilize whole system. This is achieved by applying pull springs. Driven force is generated by vibrators, which are connected with the riddle elements. The screen drive system must cooperate in the conditions of synchronization (the same angular velocity of shaft rotation). Soft start of the drive system provides a motion of riddle. Here, small amplitude and high frequency motion can be obtained. There is no sieve motion until the material contacts with the sieve surface. Gravity forces of following material moves out the sieve from the equilibrium and provides the lateral sieve motion $\left(v_{s}\right)$ with relatively large amplitude. The material movement along the sieve is the result of complex screen motion and inclination angle $(\alpha)$, which determinates the material velocity rate on the sieve surface. The motion of parametric resonance screener enables to process easily fine granular materials and may increase efficiency of the screening process. Unfortunately this screening system is unstable. The proper operation of this machine depends on many construction parameters e.g. value of driven force, the sieve pretension force, fatigue strength of sieve material.

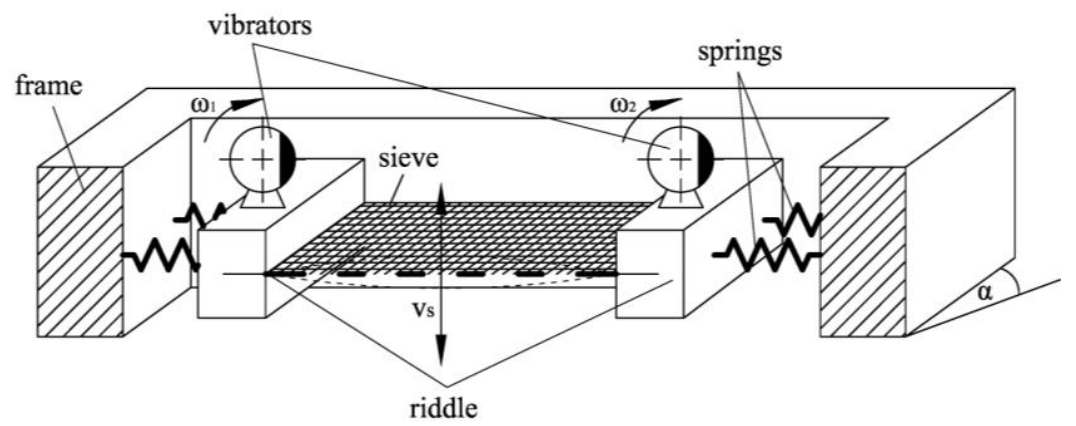

Fig. 4. Scheme of parametric resonance screener

\section{The PR-base laboratory screener}

To investigate the influence of each construction parameter the laboratory prototype of parametric resonance screener is needed. Screener construction enables adjustment of primary machine parameters:

- angular velocity of electrical vibrators, 
- inclination angle of sieve surface,

- quantity of feed,

- pretention of sieve.

Investigation of these parameters in the wide range will be helpful to stabilize the process run. It is also very important in the development of industrial PRbased screeners.

The model of laboratory PR-based screener is shown in Fig. 5. It is double frame construction. This solution allows adjusting the sieve inclination angle. The range of angle adjustment between 20 and 40 degrees is controlled 2.5 degree increments. The suspension system off riddle is placed on the movable
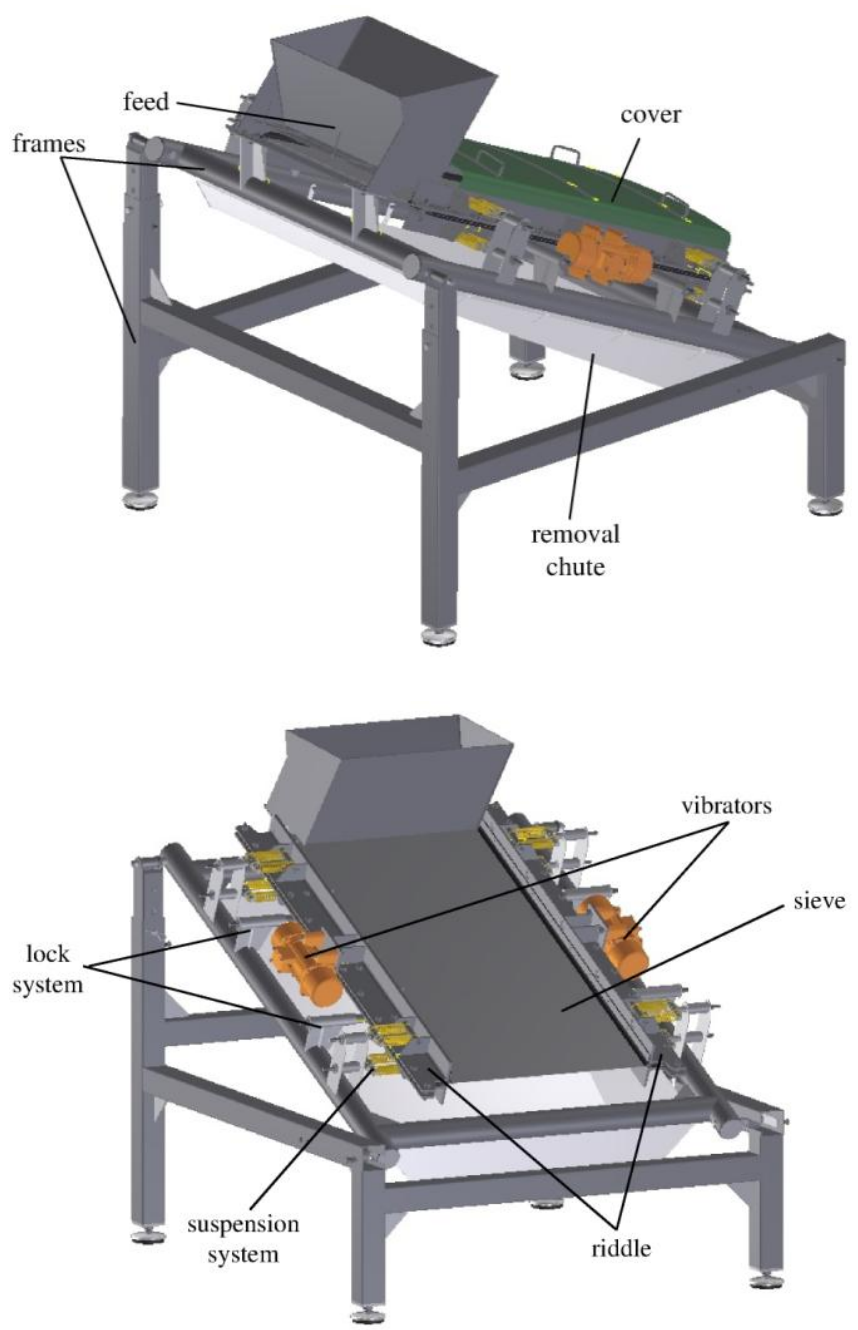

Fig. 5. Model of laboratory parametric resonance screener 
frame (Fig. 6). It consists the set of sixteen springs connected with the pin ended by screw. Adjustment of preload is obtained by movement of spring's fixtures. The screener transport and it's damage repair need to fix parts of the riddle. Thus, locking system is designed in the frame. Locking pins enable easy change of the sieve and other parts which can be damaged.

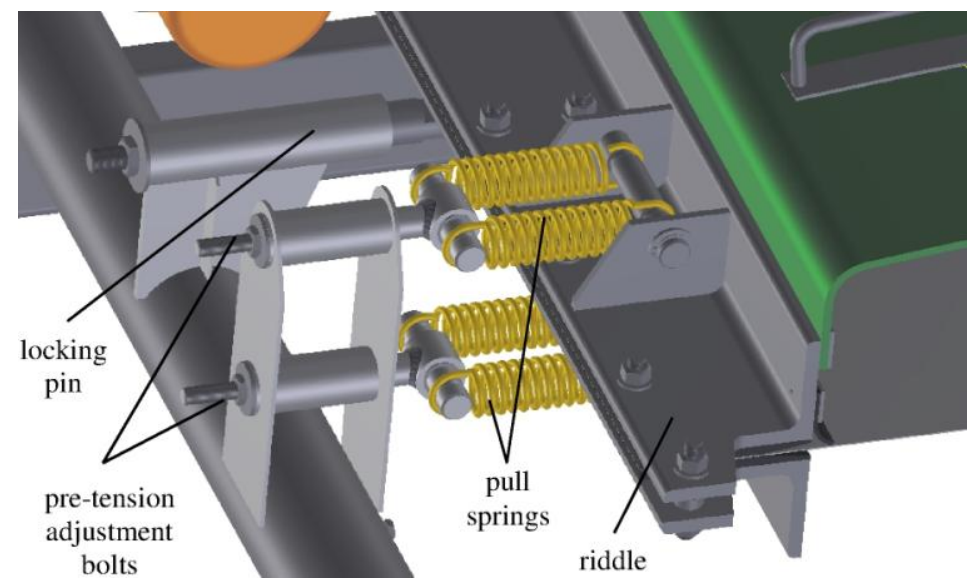

Fig. 6. The suspension system of PR screener

The riddle is designed as the assembly couple of two angle sections (Fig. 7). They are connected to each other by bolts and fixed the sieve simultaneously. Rubber elements between angle sections are applied. They perform a damping function thereby they decrease the vibration sieve effect on the other elements. To reduce the bending stresses on the sieve the shape rubber is used. The area between rubber and sieve is protected from blocking by rubber insulation element. The sieve is one of the most important elements of parametric resonance screener. In this model the sieve is a rectangular steel plate $1.0 \times 1.5$ $\mathrm{m}$ one millimetre thick with the set of rectangular cut-outs (Fig. 8). This shape of cut-outs provides very efficient screening process of fine granular material, without clogging it.

The screener is driven by two eccentric vibrators. They are placed in a both parts of the riddle (Fig. 5). Rotational speed of vibrators is adjusted continuously from 0 to $6000 \mathrm{rpm}$ by using of inverter. Thus the lateral motion of large frequency range can be obtained. The vibrators are equipped with regulated eccentric mass. This allows for different centrifugal force which will be useful to investigate a proper configuration. Material is feed onto the sieve surface by the bunker, which is fixed to the frame. The amount of material is adjusted using a slide valve (Fig. 9). The displacement of valve is limited by guard finger, which is put in suitable hole. This solution will be helpful to define production parameters of the screener and material impact on the process execution service. 


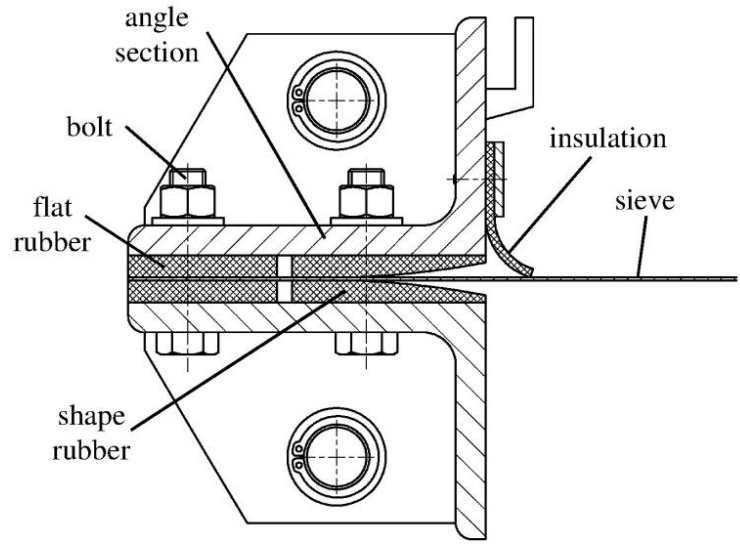

Fig. 7. The cross section of single riddle element
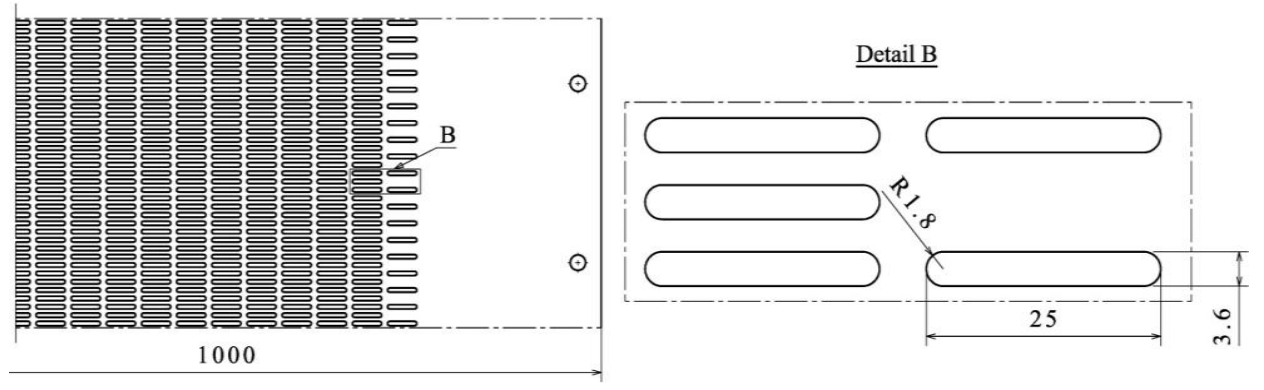

Fig. 8. The enlargement of the screen geometry

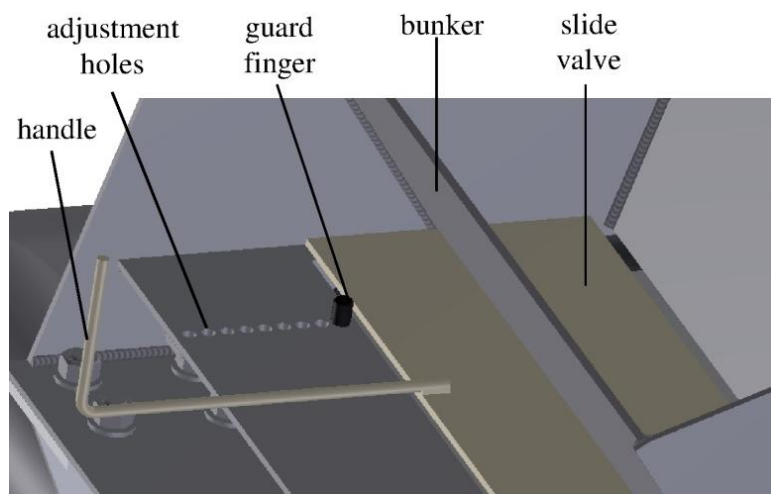

Fig. 9. Feed system

\section{References}

[1] Wodziński P.: Fine screening and screens, J. Polish Mineral Eng. Soc., 1 (2001), 41-57.

[2] Dyr T., Wodziński P.: Model particle velocity on a vibrating surface, Physicochemical Problems of Mineral Processing, 36 (2002), 147-157. 
[3] Poćwiardowski W., Wodziński P.: Przesiewanie surowców mineralnych na przesiewaczu zataczającym, Prace Naukowe Instytutu Górnictwa Politechniki Wrocławskiej, 132 (2011), 225-236.

[4] Wodziński P.: Screens - classification and systematic single-plane screens, Physicochemical Problems of Mineral Processing, 41 (2007), 237-249.

[5] Meinel A.: Fine and very fine screening, AT Mineral Processing English Edition, 1 (2010), 2-8.

[6] Dietrych D.: Teoria i budowa przesiewaczy, Wydawnictwo Górniczo-Hutnicze, Katowice 1962.

[7] Sztaba K.: Przesiewanie, Śląskie Wydawnictwo Techniczne, Katowice 1993.

[8] Banaszewski T.: Przesiewacze, Wydawnictwo Śląsk, Katowice 1990.

[9] Slepyan V.I., Loginov I.G., Slepyan L.: The method of resonance excitation of screen mesh and the screen for its implementation, Ukrainian patent no. 87369, 2009.

\section{Acknowledgement}

This work was supported by the European Research Agency - FP7-PEOPLE-2011-IAPP - Marie Curie Industry-Academia Partnerships and Pathways, grant agreement No. 284544.

\section{ZASTOSOWANIE REZONANSU PARAMETRYCZNEGO W KONSTRUKCJI PRZESIEWACZA}

\section{Streszczenie}

Zwiększenie wydajności procesu przesiewania w przemyśle wydobywczym, budowlanym itp. jest głównym powodem opracowywania coraz to nowszych konstrukcji przesiewaczy. Intensywny rozwój technik przesiewania oraz konstrukcji przesiewaczy można było zaobserwować w przeszłości. Obecnie nastąiła stabilizacja rozwiązań konstrukcyjnych, przez co większość urządzeń produkowanych przez różne firmy jest podobna. Mimo to nadal istnieje potrzeba zwiększenia efektywności eksploatacyjnej przesiewaczy. Zarówno zwiększenie wydajności oraz efektywności procesu przesiewania, jak również zmniejszenie szkodliwego oddziaływania ekologicznego to główne przesłanki rozwoju nowych maszyn przesiewających. Inwencyjną metodą zastosowaną w konstrukcji maszyn przesiewających jest wzbudzanie rezonansu parametrycznego sita przesiewacza. W pracy zaprezentowano model konstrukcyjny przesiewacza materiałów drobnoziarnistych, oparty na rezonansie parametrycznym. Przedstawiono zasadę działania przesiewacza, gdzie możliwe jest osiąnięcie złożonego ruchu sita, który jest pożądany w przypadku przesiewania materiałów w postaci wilgotnych granulatów.

Słowa kluczowe: przesiewacz, rezonans parametryczny, sito, konstrukcja

DOI:10.7862/rm.2013.10

Otrzymano/received: 11.05.2013

Zaakceptowano/accepted: 25.06.2013 